\title{
Endoscopic capture of Anisakis larva (a video demonstration)
}

\author{
Mamiko Imanishi, ${ }^{1}$ Masami Sato, ${ }^{1}$ Yasuharu Tokuda ${ }^{2}$ \\ ${ }^{1}$ Department of Gastuenterology, Mito Kyodo General Hospital, Tsukuba University, Mito City, labraki, Japan; \\ 2Department of Medicine, Mito Kyodo General Hospital, General Internal Medicine, Tsukuba University, Mito City, Ibaraki, Japan
}

Correspondence to Professor Yasuharu Tokuda, yasuharu.tokuda@gmail.com

\section{DESCRIPTION}

A 49-year-old Japanese man presented to the hospital with a 3-day history of abrupt-onset sharp epigastric pain. $\mathrm{He}$ reported that he had eaten raw salmon and mackerel at a sushi restaurant about $6 \mathrm{~h}$ before developing epigastralgia. He did not have nausea, vomiting, diarrhoea, melena, haematemesis, fever or chills. Vital signs were normal except for tachycardia (pulse rate 100/min). The physical examination revealed moderate tenderness on the epigastrium without guarding or rebound tenderness. Laboratory evaluation was unremarkable. Simple x-ray showed no abnormality. Oesophagogastroduodenoscopy revealed multiple thread-like moving worms, Anisakis larvae, in the great curvature of the middle body and fundus. The larvae were successfully removed by endoscopic forceps, including the swimming one over the gastric mucosa (video 1). The pain was relieved as soon as endoscopic removal of the larvae. Acute gastric anisakiasis is caused by gastric mucosal penetration of the Anisakis larvae and should be suspected among those who develop abrupt-onset severe sharp epigastric pain typically a few hours after eating raw or undercooked seafood. ${ }^{1}$ Although anisakiasis was seen inclusively in Japan in the past, it has become an illness of concern in many countries, including the UK, where eating Japanese style raw or undercooked seafood, such as 'sushi' and 'sashimi', has become popular. ${ }^{2}$ Because the most effective treatment is an endoscopic removal of the nematode larvae, early performance of endoscopy is highly recommended.

Video 1 Endoscopic capture of nematode Anisakis larva. 10.1136/bcr.03.2012.6068v1

Competing interests None.

Patient consent Obtained.

\section{REFERENCES}

1. Muraoka A, Suehiro I, Fujii M, et al. Acute gastric anisakiasis: 28 cases during the last 10 years. Dig Dis Sci 1996;41:2362-5.

2. Zullo A, Hassan C, Scaccianoce G, et al. Gastric anisakiasis: do not forget the clinical history! J Gastrointestin Liver Dis 2010;19:359.

This pdf has been created automatically from the final edited text and images.

Copyright 2012 BMJ Publishing Group. All rights reserved. For permission to reuse any of this content visit http://group.bmj.com/group/rights-licensing/permissions.

BMJ Case Report Fellows may re-use this article for personal use and teaching without any further permission.

Please cite this article as follows (you will need to access the article online to obtain the date of publication).

Imanishi M, Sato M, Tokuda Y. Endoscopic capture of Anisakis larva (a video demonstration). BMJ Case Reports 2012;10.1136/bcr.03.2012.6068, Published XXX

Become a Fellow of BMJ Case Reports today and you can:

- Submit as many cases as you like

- Enjoy fast sympathetic peer review and rapid publication of accepted articles

- Access all the published articles

- Re-use any of the published material for personal use and teaching without further permission

For information on Institutional Fellowships contact consortiasales@bmjgroup.com

Visit casereports.bmj.com for more articles like this and to become a Fellow

Keep up to date with all published cases by signing up for an alert (all we need is your email address) http://casereports.bmj.com/cgi/alerts/etoc 